\title{
Isolated pulmonary mucormycosis
}

\section{in an immunocompetent patient: a case report and systematic review of the literature}

\author{
Jianhan $\mathrm{He}^{1 \dagger}$, Gaohong Sheng ${ }^{2 \dagger}$, Huihui Yue ${ }^{1}$, Fengqin Zhang ${ }^{1}$ and Hui-Lan Zhang ${ }^{1 *}$ (D)
}

\begin{abstract}
Background: Pulmonary mucormycosis caused by Mucorales is a highly lethal invasive fungal infection usually found in immunocompromised patients. Isolated pulmonary mucormycosis in immunocompetent patients is very rare. Here, we present a case of a 32-year-old male who developed pulmonary mucormycosis without any known immunodeficiency.
\end{abstract}

Case presentation: The patient presented to our hospital because of cough and chest pain along with blood in the sputum. He was first treated for community-acquired pneumonia until bronchoalveolar lavage fluid culture confirmed the growth of Absidia. His symptoms were relieved with the use of amphotericin B, and he eventually recovered. We also provide a systematic review of relevant literature to summarize the characteristics of pulmonary mucormycosis in immunocompetent patients.

Conclusions: Pulmonary mucormycosis has variable clinical presentations and is difficult to identify. Due to its high fatality rate, clinicians should make judgements regarding suspected cases correctly and in a timely manner to avoid misdiagnosis and delayed treatment.

Keywords: Pulmonary mucormycosis, Immunocompetent host, Systematic review, Case report

\section{Background}

Mucormycosis is an opportunistic infection caused by Mucorales, including Absidia, Rhizopus, Rhizomucor, Mucor, and Cunninghamella, among others, fungi that can invade the nose, sinuses, brain, gastrointestinal tract, skin, and lung or even disseminate throughout the body [1]. Absidia, Rhizopus, and Rhizomucor are the most common types of Mucorales isolated from patients with mucormycosis. Mucorales species are ubiquitous saprophytes, and soil is believed to be the main habitat

\footnotetext{
*Correspondence: huilanz_76@163.com

†Jianhan He and Gaohong Sheng contributed equally to this work

${ }^{1}$ Department of Respiratory and Critical Care Medicine, Tongji

Hospital of Tongji Medical College, Huazhong University of Science

and Technology, Jie Fang Road, Han Kou District, Wu Han 1095430030,

HuBei Province, China

Full list of author information is available at the end of the article
}

of most of these fungi. The sporangiospores released by Mucorales range from 3 to $11 \mu \mathrm{m}$ in diameter and can be aerosolized to disperse in the environment, leading to an airborne infection in the upper or lower airways [2].

Pulmonary mucormycosis is the third most common presentation of mucormycosis and is known for its aggressive clinical course, with a mortality rate of over $50 \%$ [3]. This highly lethal fungal infection is usually found in immunocompromised patients with haematological malignancy or diabetes or who receive long-term immunosuppressive therapy after haematopoietic stem cell transplantation or solid organ transplantation or have autoimmune diseases [4]. However, pulmonary mucormycosis can, albeit rarely, occur in patients without any of the above-mentioned risk factors. Because of its nonspecific presentations, pulmonary mucormycosis is easily misdiagnosed, especially in immunocompetent patients, 
which would result in serious consequences. The increasing incidence over the past few decades makes it a great threat to human health [5].

As one of the most common pathogens of mucormycosis, Absidia (also known as Lichtheimia) is most likely to affect the skin and subcutaneous tissue. Absidia can also invade the lung, causing pathological alterations characterized by vascular invasion, thrombosis, and tissue necrosis [6]. Herein, we report a case of isolated pulmonary mucormycosis caused by Absidia in an adult male with no known immunodeficiency and provide a systematic review of the relevant literature to summarize the characteristics of pulmonary mucormycosis. We hope that this case will help clinicians identify pulmonary mucormycoses as early as possible, especially in immunocompetent patients, to improve therapeutic efficacy and prognosis.

\section{Case presentation}

A 32-year-old male presented to our hospital in January 2018 because of cough and chest pain along with blood in the sputum. His chest pain was on the right side and was significantly aggravated by deep breathing. The above symptoms started after he became chilled 5 days prior and were exacerbated without obvious inducements 2 days prior. After receiving anti-infection treatment in the outpatient department for 2 days with little improvement, he was admitted to our hospital for further diagnosis and treatment.

He denied a history of hypertension, diabetes, coronary heart diseases, or infections such as hepatitis B and tuberculosis. Relevant laboratory findings were as follows: white blood cell: $13.54 \% 10^{9} / \mathrm{L}$ (reference interval: 3.50-9.50*10\% $/$ L); neutrophil\%: $87.1 \%$ (RI: $40.0-75.0 \%$ ); lymphocyte\%: $10.2 \%$ (RI: 20.0-50.0\%); hypersensitive C-reactive protein: $92.9 \mathrm{mg} / \mathrm{L}$ (RI: $<1 \mathrm{mg} / \mathrm{L})$; D-dimer: $1.37 \mu \mathrm{g} / \mathrm{ml}(\mathrm{RI}:<0.5 \mu \mathrm{g} / \mathrm{ml})$. Influenza and parainfluenza IgM antibodies were tested, and the results were negative. No obvious abnormalities were found on an electrocardiogram or for the rheumatic immune system, routine urine and liver function, electrolyte or renal function. Fibreoptic bronchoscopy and sputum smear did not show any abnormalities. Chest CT imaging suggested pulmonary infection with pleural effusion (Fig. 1a), which was confirmed by pleural ultrasonography. Therefore, he continued to be treated for severe community-acquired pneumonia.

Two days after admission, he developed a fever with a temperature of $37.5^{\circ} \mathrm{C}$, with no relief of chest pain. Given this, we considered the possibility of tuberculosis. However, no acid-fast bacilli were found in sputum smears or by T-SPOT. A TB test was nonreactive. The results of gene X-pert and acid-fast staining along with that of tuberculous culture, which was obtained a few days later, were all negative. Seven days after admission, his chest a
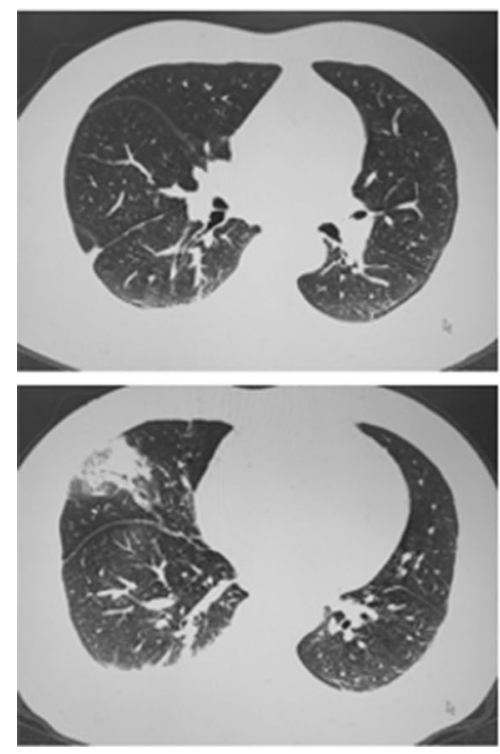

b
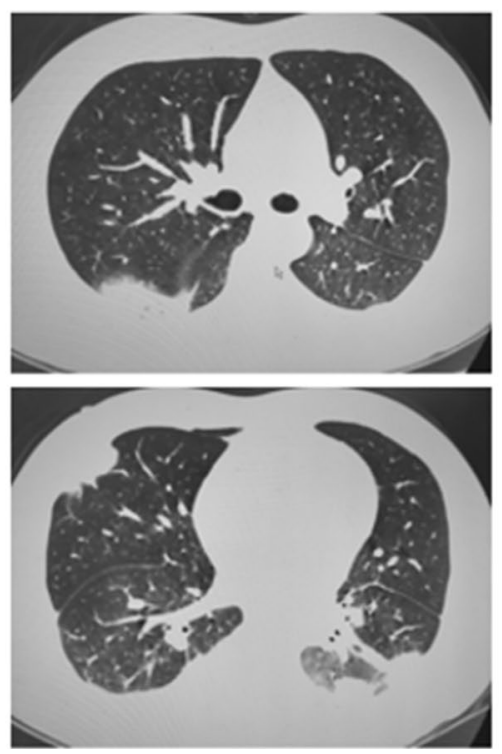

C
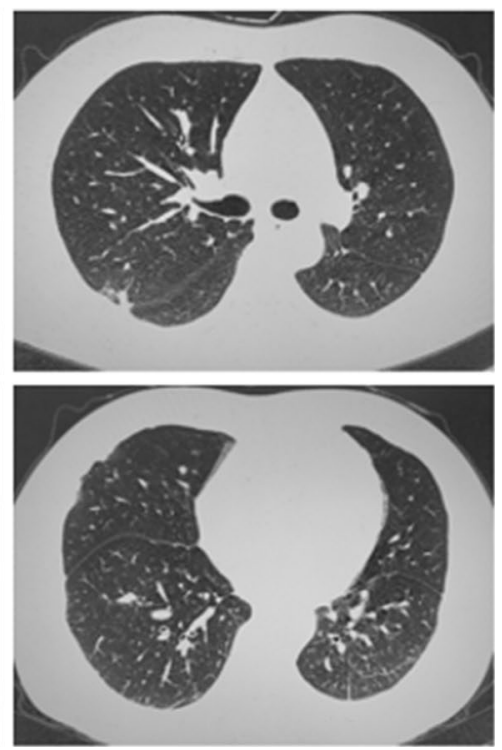

Fig. 1 Chest CT scan (a). Upon arrival: chest CT imaging suggested pulmonary infection with pleural effusion (b). Seven days after admission: chest CT imaging suggested more extensive pulmonary infection with pleural effusion (c). Seventy days after admission: signs of lung infection were dramatically improved, and pleural effusion was also obviously absorbed 
pain significantly worsened. Enhanced chest CT imaging showed bilateral pulmonary embolism of the secondary pulmonary artery and its far branch, bilateral pleural effusion, and atelectasis of the lower lobe in the bilateral lungs (Fig. 1b). CT-pulmonary artery angiography one day later revealed similar results (Fig. 2). We also noted an elevation of D-dimer up to $3.51 \mu \mathrm{g} / \mathrm{ml}$. We therefore performed echocardiography and deep venous sonography to detect cardiac diseases and deep vein thrombosis, respectively, with no positive results.

We faced a clinical dilemma regarding his diagnosis and treatment; one day later, Absidia was detected in bronchoalveolar lavage fluid culture, which provided us with guidance for subsequent treatment. Given that he was a warehouse keeper and acknowledged a history of inhaling dust in the warehouse, we speculated that he may be infected by inhaling fungal spores attached to dust. Given that such fungi can invade the brain and sinuses, a CT scan of these organs was performed rapidly and showed no damage. Antifungal therapy with oral posaconazole and intravenous amphotericin B was started immediately. The patient was given $400 \mathrm{mg}$ posaconazole and $10 \mathrm{mg}$ amphotericin B on the first day followed by $20 \mathrm{mg}$ amphotericin B daily as maintenance therapy. Unsurprisingly, his symptoms, such as chest pain and cough, were relieved, and his temperature returned to normal.

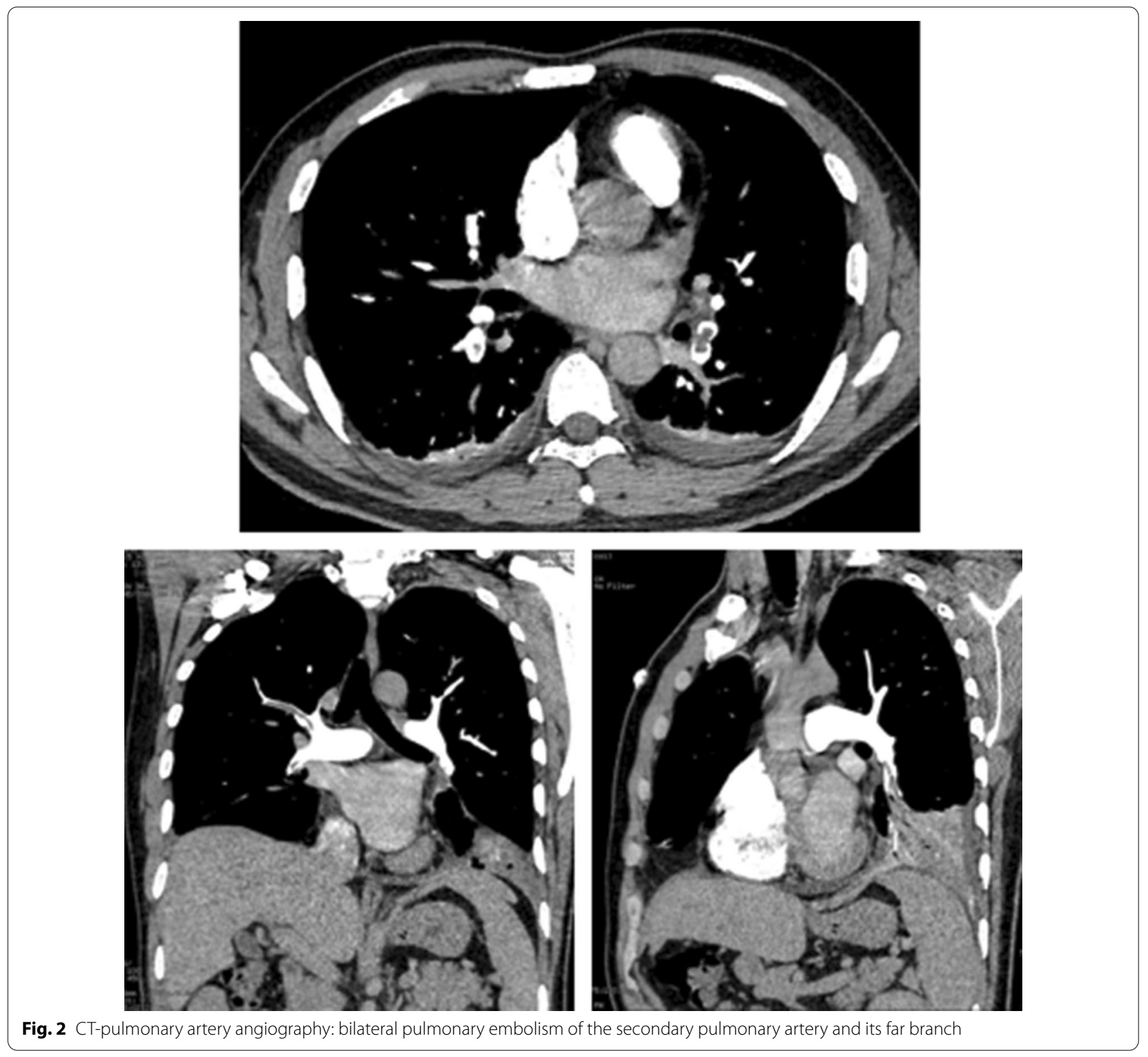


Furthermore, chest CT re-examination showed dramatic improvement in the signs of lung infection; the pleural effusion was also obviously absorbed (Fig. 1c). During follow-up for two years after discharge, he was completely cured without any recurrence or sequelae.

\section{Systematic review}

We carried out a systematic literature search in PubMed and Embase (OVID) using the following search terms: ("Rhizopus" OR "Rhizomucor" OR "Lichtheimia" OR "Absidia" OR "Mucor" OR "Mucormycosis" OR "Zygomycosis") AND ("pulmonary" OR "lung"). Only studies published in English between 1 January 2010 and 10 October 2020 were reviewed as primary screening. We included studies reporting patients diagnosed with pulmonary mucormycosis based on EORTC/MSG criteria 2018 [7]; studies were excluded if the patients were younger than 18 or had any immune deficiencies, such as diabetes, haematological malignancy, long-term immunosuppressive therapy after haematopoietic stem cell or solid organ transplantation, or autoimmune diseases. The reason for excluding subjects younger than 18 is that pulmonary mucormycosis has different clinical manifestations and outcomes in adults and children [8]. Each article was independently evaluated by two authors (Gaohong Sheng and Jianhan $\mathrm{He}$ ) according to the eligibility criteria mentioned above. Inconsistent judgements between these two researchers were settled by arbitration of the principal investigator (Hui-Lan Zhang). We extracted the basic characteristics of the studies and participants, pathogen data, clinical presentations, medical history, diagnosis, treatment, and outcome.

Fourteen articles describing 15 patients were eventually included and analysed [9-22]. The search flow diagram is shown in Fig. 3. The age of the included patients ranged from 26 to 76 years, with a male prevalence of $60 \%$, basically consistent with previous observations that fungi can affect people of almost all ages, with a male tendency [3]. The most common clinical presentations were fever and cough, with an occurrence rate of $53 \%(8 / 15)$, followed by haemoptysis $(46 \%, 7 / 15)$ and dyspnoea $(40 \%, 6 / 15)$. Interestingly, one case presented with Pancoast syndrome and bone destruction of the ribs without the above-mentioned common clinical presentations.

Almost all cases were diagnosed through bronchoalveolar lavage culture $(50 \%, 6 / 12)$ or histopathologic

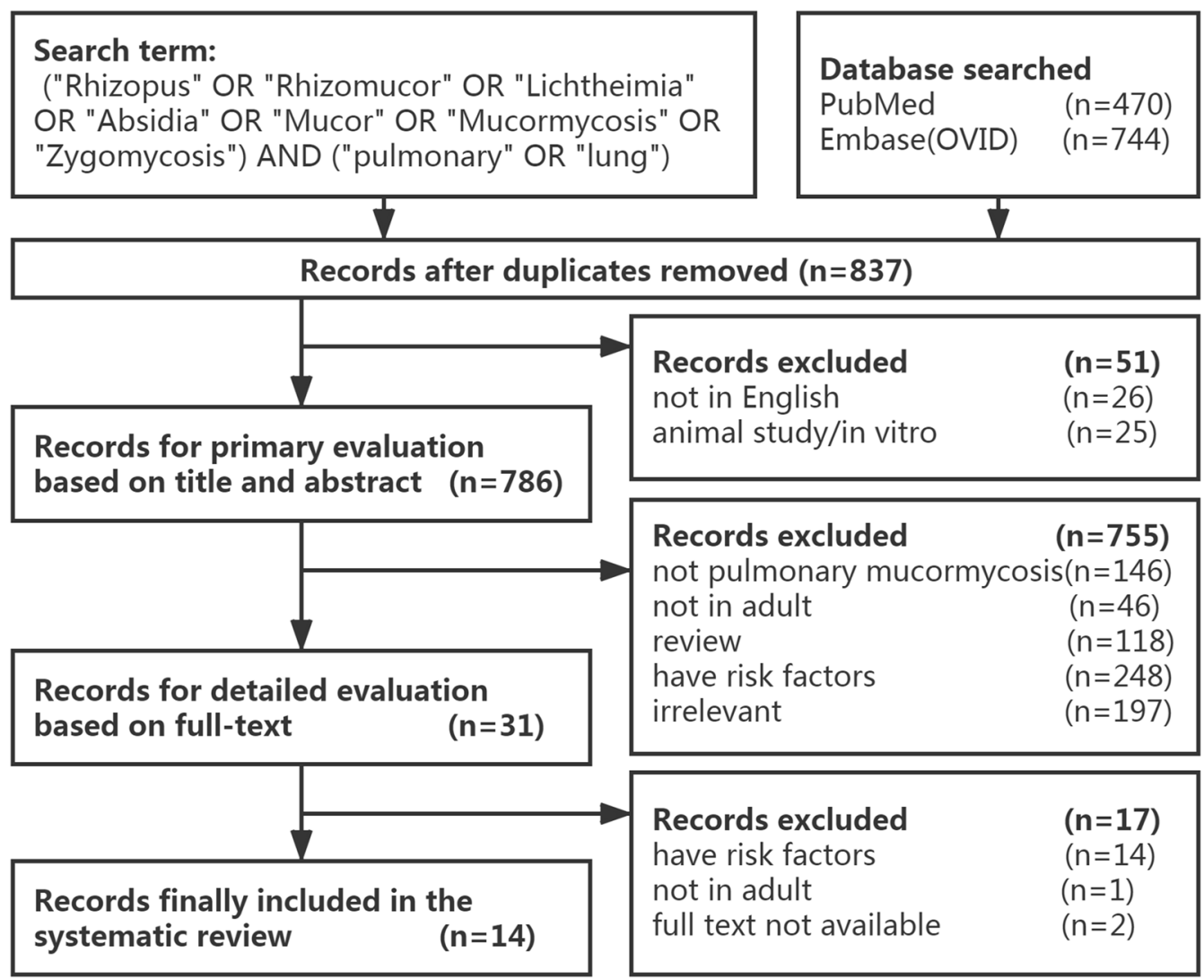

Fig. 3 Search flow diagram for the included studies 
examination of biopsy $(42 \%, 5 / 12)$; the remaining case was confirmed by autopsy. All confirmed patients with fungal infection received antifungal drugs, with an overall mortality rate of approximately $43 \%(6 / 14)$. Almost all patients $(93 \%, 14 / 15)$ were treated with amphotericin B. A total of 12 patients received amphotericin B alone, with a mortality rate of $50 \%(6 / 12)$. In two cases, amphotericin $B$ along with caspofungin or voriconazole achieved remarkable antifungal efficacy. Additionally, one patient received oral posaconazole alone as antifungal therapy; however, he eventually died of respiratory failure. We also found that two patients who underwent surgery both had encouraging outcomes, with symptom the alleviation. The mortality rate of pulmonary mucormycosis in our review $(43 \%, 6 / 14)$ was lower than that reported previously $(51 \%, 87 / 172)$ [3]. It is possible that the patients included in our study were not affected by immunosuppressive factors that render the infection less lethal. The detailed characteristics of the included patients are presented in Table 1.

Notably, two of the patients included in the review experienced liver failure with decompensated disease: one had acute liver failure, and the other had hepatic cirrhosis. Acute liver failure (ALF) shares similarities with septic shock and has the characteristics of systemic inflammation and functional immunoparesis [23]. The persistence of a compensatory anti-inflammatory response syndrome caused by acute liver failure impairs the immune system and may lead to fungal infection. Liver cirrhosis is a hallmark of immune dysfunction due to impaired antigen presentation ability in monocytes and disturbed mechanisms of antimicrobial recognition and elimination in macrophages; it is even described as one of the world's most common immunodeficiency syndromes [24]. Hence, this review supports the hypothesis that liver failure with decompensation disease might increase the risk of mucormycosis by impairing the immune system. Unfortunately, neither of these two patients survived, suggesting that decompensation of liver function may be a contributing factor to death.

\section{Discussion and conclusions}

Mucormycosis is an acute, progressive, and fatal disease that can affect people of almost all ages. Host immunosuppression appears to be the most critical risk factor for susceptibility to mucormycosis. Diabetes is also considered to be an important risk factor, as it will significantly reduce immune system function and increase the risk of various infections [4, 25]. Clinically, there are very few cases involving a normal immune system.

Our patient was a 32-year-old man with symptoms of cough, chest pain, and haemoptysis. Considering that he did not have any of the afore-mentioned risk factors, we initially suspected that he may have community-acquired pneumonia or tuberculosis until bronchoalveolar lavage fluid culture confirmed the growth of Absidia. A continuously rising D-dimer level and CT image presentation hinted at pulmonary embolism of unknown cause in this case. The manifestation of pulmonary embolisms caused by Rhizopus infection has also been reported by autopsy in a previous case [26]. In routine clinical settings, pulmonary embolism is more common in patients with acute or chronic heart disease, cancer, pregnancy, and early postpartum, as well as after surgery [27]. Nonetheless, as in our case, pulmonary mucormycosis may induce pulmonary embolism because Mucorales species tend to invade the elastic intima of large and small vessels, causing thrombosis, bleeding, and infarction, which may be a valuable clue to the correct diagnosis. Thus, clinicians must be vigilant when pulmonary embolism of an unknown cause occurs in patients with signs of lung infection, and they should fully evaluate the possibility of pulmonary mucormycosis. In addition, it was a dilemma for us to decide whether to use anticoagulant or thrombolytic therapy when thrombosis was detected because such therapy may result in adverse consequences. We suggest that thrombolytic therapy should not be applied when the cause of embolism is unknown and the patient's vital signs are stable. Considering that pulmonary mucormycosis is an angio-invasive infection with thrombosis and tissue necrosis, antifungal agents may be less penetrating at the site of infection and result in a limited effect compared to surgical resection [28]. Remarkably, two patients who underwent surgery showed encouraging outcomes, suggesting that in addition to antifungal therapy, surgery may improve prognosis in certain cases. Consistently, a previous study reported that surgery combined with antifungal therapy reduced mortality compared with medicine alone [29]. Therefore, surgery might be recommended for specific patients who do not respond well to medication.

We speculate that our patient became infected by inhaling dust carrying spores due to his job as a warehouse keeper and his dust exposure history. Similarly, a previously reported patient from the United Kingdom who was a civil engineer with occupational exposure to soil and decaying plant matter developed rhinofacial mucormycosis. In fact, very few cases can be accurately traced back to the source of infection and the route of transmission due to widespread nature of saprophytes and their spores [2]. Nevertheless, an exposure history is a valuable clue contributing to the diagnosis of pulmonary mucormycosis. Our case also shows that people with normal immune function can become infected with fungi and develop pulmonary mucormycosis. Some studies have suggested that fungal infection may be a complication of 
Table 1 Characteristics of included studies and patients

\begin{tabular}{|c|c|c|c|c|c|c|c|c|}
\hline Author/year & Sex & Age & Pathogen & Medical history & $\begin{array}{l}\text { Clinical } \\
\text { presentation }\end{array}$ & Treatment & $\begin{array}{l}\text { Diagnosis } \\
\text { method }\end{array}$ & Outcome \\
\hline Huang et al. [9] & $\mathrm{F}$ & 60 & $\begin{array}{l}\text { Rhizomucor } \\
\text { pusillus }\end{array}$ & $\begin{array}{l}\text { Bipolar disorder, } \\
\text { hypothyroidism, } \\
\text { acute liver failure }\end{array}$ & Fever, leukocytosis & $\begin{array}{l}\text { Liposomal ampho- } \\
\text { tericin B }\end{array}$ & $\begin{array}{l}\text { Endotracheal aspi- } \\
\text { rations sample } \\
\text { culture }\end{array}$ & Died \\
\hline Yang et al. [10] & $F$ & 46 & NA & NA & $\begin{array}{l}\text { Pancoast syn- } \\
\text { drome, bone } \\
\text { destruction of } \\
\text { ribs }\end{array}$ & Posaconazole & $\begin{array}{l}\text { CT-guided percu- } \\
\text { taneous biopsy }\end{array}$ & Died \\
\hline $\begin{array}{l}\text { Santos Silva et al. } \\
\text { [11] }\end{array}$ & M & 76 & NA & $\begin{array}{l}\text { Repeated urinary } \\
\text { infections, PTB }\end{array}$ & Hemoptysis & $\begin{array}{l}\text { Liposomal } \\
\text { amphotericin B } \\
\text { surgery: middle } \\
\text { lobectomy }\end{array}$ & $\begin{array}{l}\text { Lobectomy and } \\
\text { histopathologi- } \\
\text { cal examination }\end{array}$ & Live \\
\hline Wang et al. [12] & M & 31 & NA & NA & $\begin{array}{l}\text { Cough, weight } \\
\text { loss, nausea, } \\
\text { sour regurgita- } \\
\text { tion, dyspnea, } \\
\text { hemoptysis }\end{array}$ & $\begin{array}{l}\text { Liposomal ampho- } \\
\text { tericin B }\end{array}$ & NA & Live \\
\hline $\begin{array}{l}\text { Persichino et al. } \\
\text { [13] }\end{array}$ & M & 58 & Rhizopus arrhizus & Hepatic cirrhosis & $\begin{array}{l}\text { Septic shock, acute } \\
\text { hypoxic respira- } \\
\text { tory failure }\end{array}$ & $\begin{array}{l}\text { Liposomal ampho- } \\
\text { tericin B }\end{array}$ & $\begin{array}{l}\text { Cultures of BALF } \\
\text { and swab }\end{array}$ & Died \\
\hline Zubairi et al. [14] & M & 45 & $\begin{array}{l}\text { Lichtheimia cor- } \\
\text { ymbifera }\end{array}$ & NA & $\begin{array}{l}\text { Cough, fever, dysp- } \\
\text { nea, hemoptysis, } \\
\text { rapid dete- } \\
\text { rioration of both } \\
\text { respiratory and } \\
\text { renal functions }\end{array}$ & $\begin{array}{l}\text { Amphotericin B, } \\
\text { voriconazole }\end{array}$ & BALF culture & Live \\
\hline Hirano et al. [15] & M & 74 & $\begin{array}{l}\text { Cunninghamella } \\
\text { berthollet }\end{array}$ & $\mathrm{ACO}, \mathrm{AAA}$ & Dyspnea, fever & $\begin{array}{l}\text { Liposomal ampho- } \\
\quad \text { tericin B }\end{array}$ & BALF culture & Died \\
\hline Grabala et al. [16] & $\mathrm{F}$ & 41 & Mucor & NA & $\begin{array}{l}\text { Cough, hemopty- } \\
\text { sis, multisystem } \\
\text { organ failure }\end{array}$ & $\begin{array}{l}\text { Caspofungin, } \\
\text { amphotericin B }\end{array}$ & BALF culture & Live \\
\hline Yan et al. [17] & $\mathrm{F}$ & $55 \& 66$ & Mucor & NA & $\begin{array}{l}1 \text { Fever, } 2 \text { cough, } 2 \\
\text { hemoptysis }\end{array}$ & $\begin{array}{l}1 \text { Liposomal } \\
\text { amphotericin B } \\
\text { 1surgery }\end{array}$ & NA & Live \\
\hline Acharya et al. [18] & M & 44 & NA & NA & $\begin{array}{l}\text { Fever, cough, dysp- } \\
\text { nea, chest pain }\end{array}$ & $\begin{array}{c}\text { Amphotericin B } \\
\text { deoxycholate }\end{array}$ & Biopsy & NA \\
\hline Koneru et al. [19] & $\mathrm{F}$ & 48 & NA & NA & $\begin{array}{l}\text { Fever, dyspnea, } \\
\text { hypoxemic res- } \\
\text { piratory failure }\end{array}$ & Amphotericin B & Autopsy & Died \\
\hline $\begin{array}{l}\text { Jayakrishnan et al. } \\
\text { [20] }\end{array}$ & M & 26 & Mucor & NA & $\begin{array}{l}\text { Vomiting, dyspnea, } \\
\text { cough, fever, } \\
\text { renal failure }\end{array}$ & $\begin{array}{l}\text { Liposomal ampho- } \\
\text { tericin B }\end{array}$ & BALF culture & Died \\
\hline Sarkar et al. [21] & M & 70 & Mucor & NA & Fever, hemoptysis & $\begin{array}{l}\text { Liposomal ampho- } \\
\text { tericin B }\end{array}$ & $\begin{array}{l}\text { CT -guided fine } \\
\text { needle aspiration } \\
\text { cytology and } \\
\text { true cut biopsy }\end{array}$ & Live \\
\hline Lee et al. [22] & M & 52 & NA & $\begin{array}{l}\text { COPD, PTB, hepa- } \\
\text { titis C }\end{array}$ & Cough & Amphotericin B & $\begin{array}{l}\text { Transcutaneous } \\
\text { needle biopsy }\end{array}$ & Live \\
\hline
\end{tabular}

M, male; F, female; NA, not available; COPD, chronic obstructive pulmonary disease; ACO, asthma-COPD overlap; BALF, Bronchoalveolar lavage Fluid; PTB, pulmonary tuberculosis; AAA, abdominal aortic aneurysm

influenza virus infection [30], but recent influenza and parainfluenza IgM antibody tests showed that the patient was not infected with influenza or parainfluenza. We also assessed the possibility of medications such as steroids inducing fungal infection in this patient; however, he had only received cefotaxime sulbactam and levofloxacin in the outpatient department prior to hospitalization.
In general, non-specific symptoms such as fever, cough, dyspnoea, haemoptysis and chest pain are the most common clinical manifestations in patients with pulmonary mucormycosis. The variable presentations make it difficult for doctors to distinguish pulmonary mucormycosis from other pulmonary diseases. Furthermore, fiberoptic bronchoscopy and sputum smear 
were prone to miss the detection of fungal infection. The definitive diagnosis of pulmonary mucormycosis should rely on the identification of typical hyphae through bronchoalveolar lavage culture, needle biopsy, and resected lung tissue biopsy [31]. However, such invasive operations possibly should not be initially performed for patients without any risk factors, and obtaining results from culture also takes a long time. These limitations of detection would lead to a delay of diagnosis and the initiation of systemic antifungal therapy, which would further worsen prognosis and even increase the risk of death.

Above all, pulmonary mucormycosis is an opportunistic infection caused by Mucorales. Such fungal infection mainly occurs in patients with immune system deficiency, though it can rarely attack immunocompetent patients. Due to its high fatality rate, clinicians should make judgements on suspected cases correctly and in a timely manner to avoid misdiagnosis and delayed treatment. Early diagnosis of pulmonary mucormycosis remains a clinical challenge due to the lack of specific clinical manifestations. First, it is essential for clinicians to keep in mind that pulmonary mucormycosis might occur in patients with normal immune function, especially when routine anti-infective treatments fail. Second, clinicians should be cautious with the occurrence of pulmonary embolism in patients with signs of lung infection. Third, it is important to carefully review the exposure history. Here, we present an immunocompetent case and summarize the characteristics of patients with pulmonary mucormycosis with normal immune function in the literature. We aim to provide a wide range of ideas for clinicians during diagnosis and to prevent delayed diagnosis and treatment or even misdiagnosis for such immunocompetent cases to ultimately improve the prognosis and decrease the risk of death.

\section{Abbreviations}

RI: Reference interval; CT: Computed tomography.

\section{Authors' contributions}

$\mathrm{HZ}$ is the guarantor of this study and takes responsibility for the work, and was responsible for the design of the whole study and the interpretation of the collected data. JH and GS contributed to collecting and filtering the data and drafting and revising the manuscript. HY and FZ contributed to collecting the data for our case and revising the manuscript. All authors have read and approved the manuscript.

\section{Availability of data and materials}

The data are available from the authors upon reasonable request.

\section{Declarations}

Ethics approval and consent to participate

Not applicable.

\section{Consent for publication}

Written informed consent was obtained from the patient for the publication of this case report and any accompanying images. The data presented in this case report do not allow identification of the patient.

\section{Competing interests}

No conflicts of interest were declared by the authors.

\section{Author details}

${ }^{1}$ Department of Respiratory and Critical Care Medicine, Tongji Hospital of Tongji Medical College, Huazhong University of Science and Technology, Jie Fang Road, Han Kou District, Wu Han 1095430030, HuBei Province, China. ${ }^{2}$ Department of Orthopedics, Tongji Hospital, Tongji Medical College, Huazhong University of Science and Technology, Jiefang Avenue 1095, Wuhan 430030, China.

Received: 5 February 2021 Accepted: 19 April 2021

Published online: 27 April 2021

\section{References}

1. Petrikkos G, Skiada A, Lortholary O, Roilides E, Walsh TJ, Kontoyiannis DP. Epidemiology and clinical manifestations of mucormycosis. Clin Infect Dis Off Publ Infect Dis Soc Am. 2012;54(Suppl 1):S23-34.

2. Richardson M. The ecology of the Zygomycetes and its impact on environmental exposure. Clin Microbiol Infect Off Publ Eur Soc Clin Microbiol Infect Dis. 2009;15(Suppl 5):2-9.

3. Jeong W, Keighley C, Wolfe R, Lee WL, Slavin MA, Kong DCM, Chen SC. The epidemiology and clinical manifestations of mucormycosis: a systematic review and meta-analysis of case reports. Clin Microbiol Infect Off Publ Eur Soc Clin Microbiol Infect Dis. 2019;25(1):26-34.

4. Lanternier F, Lortholary O. Zygomycosis and diabetes mellitus. Clin Microbiol Infect Off Publ Eur Soc Clin Microbiol Infect Dis. 2009;15(Suppl 5):21-5.

5. Lin E, Moua T, Limper AH. Pulmonary mucormycosis: clinical features and outcomes. Infection. 2017;45(4):443-8.

6. Schwartze VU, Jacobsen ID. Mucormycoses caused by Lichtheimia species. Mycoses. 2014;57(Suppl 3):73-8.

7. Donnelly JP, Chen SC, Kauffman CA, Steinbach WJ, Baddley JW, Verweij PE, Clancy CJ, Wingard JR, Lockhart SR, Groll AH, et al. Revision and update of the consensus definitions of invasive fungal disease from the european organization for research and treatment of cancer and the mycoses study group education and research consortium. Clin Infect Dis Off Publ Infect Dis Soc Am. 2020;71(6):1367-76.

8. Roilides E, Zaoutis TE, Walsh TJ. Invasive zygomycosis in neonates and children. Clin Microbiol Infect Off Publ Eur Soc Clin Microbiol Infect Dis. 2009;15(Suppl 5):50-4.

9. Huang YQ, Tremblay JA, Chapdelaine H, Luong ML, Carrier FM. Pulmonary mucormycosis in a patient with acute liver failure: a case report and systematic review of the literature. J Crit Care. 2020;56:89-93.

10. Yang J, Zhang J, Feng Y, Peng F, Fu F. A case of pulmonary mucormycosis presented as Pancoast syndrome and bone destruction in an immunocompetent adult mimicking lung carcinoma. J Mycol Med. 2019;29(1):80-3.

11. Santos Silva J, Torres C, Clemente S, Calvinho P. Isolated Pulmonary Mucormycosis in an immunocompetent patient. Rev Portuguesa de cirurgia cardio-toracica e vascular : orgao oficial da Sociedade Portuguesa de Cirurgia Cardio-Toracica e Vascular. 2019;26(2):151-3.

12. Wang LH, Lan F, Tan YB, Tang JL. Mucormycosis lung cavity accompany with serum IgG4 elevation: a case report. Int J Clin Exp Med. 2018:11(10):11294-8.

13. Persichino JG, Can AD, Van TT, Matthews MN, Filler SG. Invasive pulmonary mucormycosis and aspergillosis in a patient with decompensated hepatic cirrhosis. Med Mycol Case Rep. 2018;21:12-5.

14. Zubairi ABS, Idrees F, Jabeen $K$, Kamal S, Zafar A. Coinfection with Lichtheimia corymbifera and Aspergillus flavus in an immune-competent patient mimicking as pulmonary-renal syndrome. Mycopathologia. 2017;182(7-8):727-31. 
15. Hirano T, Yamada M, Sato K, Murakami K, Tamai T, Mitsuhashi Y, Tamada T, Sugiura H, Sato N, Saito R, et al. Invasive pulmonary mucormycosis: rare presentation with pulmonary eosinophilia. BMC Pulm Med. 2017;17(1):76.

16. Grabala J, Grabala M, Onichimowski D, Grabala P. Possibilities of using ultrasound for diagnosis of invasive pulmonary mucormycosis-a case study. Pol Ann Med. 2017;24(2):224-7.

17. Yan X, Zong F, Kong H, Wang Y, Zhao X, Liu W, Wang Z, Xie W. Pulmonary fungal diseases in immunocompetent hosts: a single-center retrospective analysis of 35 subjects. Mycopathologia. 2016:181(7-8):513-21.

18. Acharya S, Shukla S, Noman O, Dawande P. Isolated pulmonary mucormycosis presenting as cavitary lesion in an immunocompetent adult: a rare case report. Int J Appl Basic Med Res. 2016;6(1):73-4.

19. Koneru, H. A "brush" with death: opportunistic infection in an immunocompetent host. In: Chest Conference: CHEST 2015, 148(4 MEETING ABSTRACT).

20. Jayakrishnan B, Al Aghbari J, Rizavi D, Srinivasan S, Lakhtakia R, Al Riyami D. Chronic renal failure presenting for the first time as pulmonary mucormycosis with a fatal outcome. Case Rep Nephrol. 2015;2015:589537.

21. Sarkar S, Jash D, Maji A, Maikap MK. Solitary pulmonary nodule: a rare presentation of pulmonary mucormycosis in an immunocompetent adult. Lung India Off Organ Indian Chest Soc. 2014;31(1):70-2.

22. Lee JS, Kim HC, Park SW, So HS, Woo CY, Choi JH, Kim SH, Kim SJ, Oh YM. A case of isolated pulmonary mucormycosis in an immunocompetent host. Tubercul Respir Dis. 2013;74(6):269-73.

23. Antoniades CG, Berry PA, Wendon JA, Vergani D. The importance of immune dysfunction in determining outcome in acute liver failure. J Hepatol. 2008:49(5):845-61.

24. Wilde B, Katsounas A. Immune dysfunction and albumin-related immunity in liver cirrhosis. Mediators Inflamm. 2019;2019:7537649.
25. Berbudi A, Rahmadika N, Tjahjadi Al, Ruslami R. Type 2 diabetes and its impact on the immune system. Curr Diabetes Rev. 2020;16(5):442-9.

26. Kogure Y, Nakamura F, Shinozaki-Ushiku A, Watanabe A, Kamei K, Yoshizato T, Nannya Y, Fukayama M, Kurokawa M. Pulmonary mucormycosis with embolism: two autopsied cases of acute myeloid leukemia. Int J Clin Exp Pathol. 2014;7(6):3449-53.

27. Doherty S. Pulmonary embolism an update. Aust Fam Phys. 2017:46(11):816-20

28. Choi H, Lee H, Jeon K, Suh GY, Shin S, Kim HK, Kim K, Jeong D, Kim H. Factors affecting surgical resection and treatment outcomes in patients with pulmonary mucormycosis. J Thorac Dis. 2019;11(3):892-900.

29. Jeong W, Keighley C, Wolfe R, Lee WL, Slavin MA, Chen SC, Kong DCM. Contemporary management and clinical outcomes of mucormycosis: a systematic review and meta-analysis of case reports. Int J Antimicrob Agents. 2019;53(5):589-97.

30. van de Veerdonk FL, Kolwijck E, Lestrade PPA, Hodiamont CJ, Rijnders BJA, Vanpaassen J, Haas PJ, Oliveira dos Santos C, Kampinga GA, Bergmans DCJJ, et al. Influenza-associated aspergillosis in critically III patients. Am J Respir Crit Care Med. 2017;196(4):524-7.

31. Skiada A, Lass-Floerl C, Klimko N, Ibrahim A, Roilides E, Petrikkos G. Challenges in the diagnosis and treatment of mucormycosis. Med Mycol. 2018;56:93-101.

\section{Publisher's Note}

Springer Nature remains neutral with regard to jurisdictional claims in published maps and institutional affiliations.
Ready to submit your research? Choose BMC and benefit from:

- fast, convenient online submission

- thorough peer review by experienced researchers in your field

- rapid publication on acceptance

- support for research data, including large and complex data types

- gold Open Access which fosters wider collaboration and increased citations

- maximum visibility for your research: over $100 \mathrm{M}$ website views per year

At BMC, research is always in progress.

Learn more biomedcentral.com/submissions 